\title{
Erratum to: NPO, Internal Controls, and Supervision Mechanisms in a Developing Country
}

\section{Radiah Othman • Norli Ali}

Published online: 1 April 2014

(C) International Society for Third-Sector Research and The Johns Hopkins University 2014

\section{Erratum to: Voluntas (2014) 25:201-224 \\ DOI 10.1007/s11266-012-9335-4}

The name of the Ministries in Fig. 1 were altered in error. The textbox that contains the name of Ministry of Domestic Trade, Co-operatives and Consumerism should be Ministry of Home Affairs and the textbox which contains the name of Ministry of Home Affairs should be Ministry of Domestic Trade, Co-operatives and Consumerism.

The online version of the original article can be found under doi:10.1007/s11266-012-9335-4.

R. Othman $(\bowtie)$

School of Accountancy, College of Business, Massey University, Private Bag 11-222,

Palmerston North, New Zealand

e-mail: r.othman@massey.ac.nz

\section{N. Ali}

Faculty of Accountancy \& Accounting Research Institute, Universiti Teknologi MARA,

Shah Alam, Malaysia

e-mail: norli170@salam.uitm.edu.my 